\title{
Localization of a Family of Muscarinic Receptor mRNAs in Rat Brain
}

\author{
Noel J. Buckley, ${ }^{1}$ Tom I. Bonner, ${ }^{1}$ and Mark R. Brannn ${ }^{2, a}$ \\ 'Laboratory of Cell Biology, National Institute of Mental Health, and Metabolic Diseases Branch, National Institute of \\ Diabetes, Digestive and Kidney Diseases, Bethesda, MD 20892
}

\begin{abstract}
A family of 4 rat muscarinic receptors $(\mathrm{m} 1, \mathrm{~m} 2, \mathrm{~m} 3$, and $\mathrm{m} 4)$ have recently been cloned and sequenced (Bonner et al., 1987). Since pharmacological probes that are presently available do not appear to distinguish among 3 of these muscarinic receptors, we constructed oligonucleotide probes corresponding to the $\mathrm{N}$-terminal sequences of the muscarinic receptors and used them to specifically localize $\mathrm{m} 1, \mathrm{~m} 2$, $\mathrm{m} 3$, and $\mathrm{m} 4 \mathrm{mRNA}$ in sections of rat brain using in situ hybridization histochemistry. Northern analysis demonstrated a 3.1 kilobase (kb) m1 mRNA, a $4.5 \mathrm{~kb}$ m3 mRNA, and a 3.3 kb m4 mRNA in cerebral cortex, striatum, hippocampus, and cerebellum. In situ hybridization histochemistry indicated a prevalence of $m 1$ mRNA in the pyramidal cell layer of the hippocampus, the granule cell layer of the dentate gyrus, the olfactory bulb, amygdala, olfactory tubercule, and piriform cortex. Caudate putamen and cerebral cortex showed moderate levels of labeling. m2 mRNA was detectable in the medial septum, diagonal band, olfactory bulb, and pontine nuclei. $\mathrm{m} 3$ and $\mathrm{m} 4 \mathrm{mRNA}$ were also prevalent in the olfactory bulb and pyramidal cell layer of the hippocampus but were present only in low levels in the dentate gyrus. m3 mRNA was present in superficial and deep layers of the cerebral cortex, whereas m4 mRNA was more evenly distributed with a slightly more intense labeling evident in the midcortical layer. In addition, $\mathrm{m} 3 \mathrm{mRNA}$ was present in a number of thalamic nuclei and brain-stem nuclei, while m4 mRNA predominated in the caudate putamen. These data offer a new basis on which to interpret the heterogeneity of muscarinic actions in the CNS.
\end{abstract}

Muscarinic receptors mediate many of the actions of ACh in the CNS (see Nathanson, 1987). Radioligand binding and autoradiographic studies have demonstrated widespread distribution of these receptors throughout the nervous system (Rotter et al., 1979; Wamsley et al., 1981; Cortes et al., 1984, 1986; Nonaka and Moroji, 1984; Cortes and Palacios, 1986; Spencer et al., 1986). A number of studies have proposed heterogeneity among muscarinic receptors on the basis of agonist and antag-

\footnotetext{
Received Nov. 17, 1987; revised Mar. 4, 1988; accepted Apr. 13, 1988.

We thank Dr. Michael Brownstein (LCB, NIMH) for synthesizing the oligodeoxynucleotide probes and for valuable discussions throughout this work, Dr. Miklos Palkovits (LCB, NIMH) ior assistance in the interpretation of some of the anatomical data, and Dr. Regina Collins (NIDDK) for her help throughout these studies.

Correspondence should be addressed to Noel J. Buckley, Laboratory of Cell Biology, National Institute of Mental Health, Bldg. 36, Rm. 3A-17, Bethesda, MD 20892

a Present address: Laboratory of Molecular Biology, NINCDS, Bldg. 36, Rm. 30-02, Bethesda, MD 20892.

$0270-6474 / 88 / 124646-07 \$ 02.00 / 0$
}

onist selectivity (Birdsall et al., 1978; Goyal and Rattan, 1978; Hammer et al., 1980, 1986) and have ultimately led to the widely accepted classification based upon the selective muscarinic antagonist, pirenzepine, which distinguishes 2 or 3 receptor subtypes (Hammer et al., 1980). At the time that this classification scheme was proposed, it was not clear whether these subtypes reflected distinct gene products or different modifications of the same protein. It is only recently that molecular cloning of a number of muscarinic receptors has demonstrated heterogeneity due to the presence of a number of related but distinct gene products (Kubo et al., 1986a, b; Bonner et al., 1987; Peralta et al., 1987). In a previous study, we reported the cloning and sequencing of 4 muscarinic receptors $(\mathrm{m} 1, \mathrm{~m} 2, \mathrm{~m} 3$, and $\mathrm{m} 4$ ), cloned from rat cerebral cortex cDNA and human genomic libraries (Bonner et al., 1987). Sequence comparison indicates that the $m 1$ and $m 2$ receptors are rat and human homologs respectively of the porcine muscarinic receptors cloned previously from cortex and atria, respectively (Kubo et al., 1986a, b; Peralta et al., 1987). Expression of the muscarinic receptor cDNAs in COS-7 cells revealed $\mathrm{m} 1, \mathrm{~m} 3$, and $\mathrm{m} 4$ receptors to display higher affinities toward the selective muscarinic antagonist, pirenzepine, than the $\mathrm{m} 2$ receptor (Bonner et al., 1987; Brann et al., 1987). Autoradiographic studies using ${ }^{3} \mathrm{H}$-pirenzepine have demonstrated a prevalence of high-affinity pirenzepine sites in the cerebral cortex, corpus striatum, and hippocampus, with relatively few receptors in the hindbrain or cerebellum (Wamsley et al., 1984; Cortes and Palacios, 1986; Cortes et al., 1986; Mash and Potter, 1986; Spencer et al., 1986). Parallel radioligand binding studies indicated that, under the assay conditions employed, only a single class of high-affinity pirenzepine binding sites could be distinguished. Since our own studies demonstrated the existence of at least 3 muscarinic receptors in rat cortex that could express a high affinity toward pirenzepine, it is clear that autoradiographic studies using ${ }^{3} \mathrm{H}-$ pirenzepine potentially label a multiplicity of sites, thereby revealing a composite picture of the distribution of at least 3 muscarinic receptor subtypes. Since it is presently impossible to specifically label the $\mathrm{ml}, \mathrm{m} 3$, or $\mathrm{m} 4$ gene products, we were interested to use the technique of in situ hybridization histochemistry to examine the distribution of the $\mathrm{ml}, \mathrm{m} 2, \mathrm{~m} 3$, and $\mathrm{m} 4 \mathrm{mRNAs}$ in sections of rat brain. The value of these studies lies in the ability to localize cell bodies that express muscarinic receptor subtypes as opposed to mapping the distribution of the receptor itself.

\section{Materials and Methods}

Oligonucleotide synthesis. 48-mer or 45-mer antisense cDNAs, complementary to bases 7-54 of the $\mathrm{m} 1$ receptor; ACCTCAGTGCCCCCTGCTGTCAGTCCCAACATCACTGTCTTGGCACCA bases 91-147 of the $\mathrm{m} 2$ receptor; GGATCCCTCAGTTTGGTGACCATTATCGGG- 
AACATCCTAGTCATGGTT bases 4-51 of the m 3 receptor; ACCTTGCACAGTAACAGTACAACCTCGCCTTTGTTTCCCAACATCAGC bases 7-54 of the m 4 receptor; AACTTCACGCCTGTCAATGGCAGCTCAGCCAATCAGTCTGTGCGCCTG were synthesized on an Applied Biosystems 380A DNA synthesizer, purified on a $8 \%$ denaturing polyacrylamide gel, containing $8 \mathrm{M}$ urea, followed by phenolic extraction. Probes were tailed on their 3'-ends with either ${ }^{32} \mathrm{P} \alpha$-dATP(New England Nuclear) or ${ }^{35} \mathrm{~S} \alpha$-dATP (New England Nuclear) using terminal deoxynucleotidyl transferase (BRL and Boehringer Mannheim) as described previously (Young et al., 1986). Average tail length was about 10 residues.

Northern analysis. Total mRNA was extracted from fresh rat cerebral cortex, hippocampus, striatum, and cerebellum using a guanidinium isothiocyanate extraction procedure (Chirgwin et al., 1979) and precipitated through a cesium trifluoracetate/EDTA gradient $(1.51 \mathrm{gm} / \mathrm{ml}$ density). RNA was electrophoresed (15 $\mu \mathrm{g} /$ lane) on a $1 \%$ denaturing agarose gel (6.7\% formalin) and electroblotted onto Genescreen. RNA size standards were also run (RNA ladder; BRL). Blots were prehybridized for $3 \mathrm{hr}$ at $37^{\circ} \mathrm{C}$ in $4 \times \mathrm{SSPE}, 5 \times$ Denhardts, $50 \%$ formamide, $1 \%$ SDS, $250 \mu \mathrm{g} / \mathrm{ml}$ yeast RNA, and $500 \mu \mathrm{g} / \mathrm{ml}$ herring sperm DNA. Hybridization was conducted overnight at $37^{\circ} \mathrm{C}$ in the same medium containing $10^{6} \mathrm{dpm} / \mathrm{ml}{ }^{32} \mathrm{P}$-labeled probe. Blots were washed $4 \times 15 \mathrm{~min}$ at $56^{\circ} \mathrm{C}$ in $1 \times \mathrm{SSPE}$ containing $0.1 \%$ SDS, followed by $2 \times 60 \mathrm{~min}$ washes at room temperature, blotted dry, and exposed with 2 enhancing screens for $1-2$ weeks at $-70^{\circ} \mathrm{C}$.

In situ hybridization histochemistry. The overall procedure has been described previously (Young et al., 1986). Twelve micron frozen sections of rat brain were lightly fixed in $4 \%$ formalin, acetylated, dehydrated through a graded series of alcohol, defatted in chloroform, and slightly rehydrated. Sections were hybridized overnight at $37^{\circ} \mathrm{C}$ in a 50 $\mu \mathrm{l}$ aliquot of hybridization buffer containing $4 \times$ SSC, $1 \times$ Denhardts, $50 \%$ formamide, $10 \%$ dextran sulfate, $250 \mu \mathrm{g} / \mathrm{ml}$ yeast RNA, $500 \mu \mathrm{g} /$ ml herring sperm DNA, $0.1 \mathrm{M}$ DTT, and $2 \times 10^{6} \mathrm{dpm}{ }^{35} \mathrm{~S}$-labeled probe. Sections were washed in $1 \times \mathrm{SSC}$ at $56^{\circ} \mathrm{C}$ followed by $2 \times 1 \mathrm{hr}$ washes at room temperature and rinsed in distilled water before exposure to Kodak XAR-5 film for 5 weeks.

\section{Results}

Since the muscarinic receptors belong to a family of proteins of related sequence and structure, we were concerned that our oligonucleotide probes were specific for their corresponding receptors. Muscarinic receptors share the same overall structure and a significant degree of sequence homology. The common structural features proposed for this receptor family consist of a short extracellular $\mathrm{N}$-terminus, 7 membrane spanning domains and a cytoplasmic C-terminus. Despite their considerable homology, these receptors also display a number of salient differences, notably in their amino- and carboxy-termini and in their large cytoplasmic loops that connect the proposed fifth and sixth transmembrane spanning domains (Bonner et al., 1987). In order to ensure specific hybridization of each oligonucleotide probe to its corresponding muscarinic receptor mRNA, oligodeoxynucleotide probes specific to each receptor were generated against domains of the receptor mRNA corresponding to the $\mathrm{N}$-termini of the receptors, regions that share no significant homology with any other members of the gene family. Specificity of these probes was confirmed by Northern blot analysis, which showed that each probe recognized a single unique RNA species. In some cases, further proof of specificity was provided by using probes corresponding to the unique large cytoplasmic loops of the receptors; these probes gave identical results to those obtained using the $\mathrm{N}$-terminal probes described here (data not shown).

Northern blot analysis revealed hybridizing bands in cerebral cortex, hippocampus, corpus striatum, and cerebellum using the $\mathrm{m} 1, \mathrm{~m} 3$, and $\mathrm{m} 4$ probes (Fig. 1). The approximate sizes of the bands were $3.1 \mathrm{~kb}(\mathrm{ml}), 4.5 \mathrm{~kb}(\mathrm{~m} 3)$, and $3.3 \mathrm{~kb}(\mathrm{~m} 4)$. No hybridization was seen using the $\mathrm{m} 2$ probe. $\mathrm{m} 1 \mathrm{mRNA}$ was

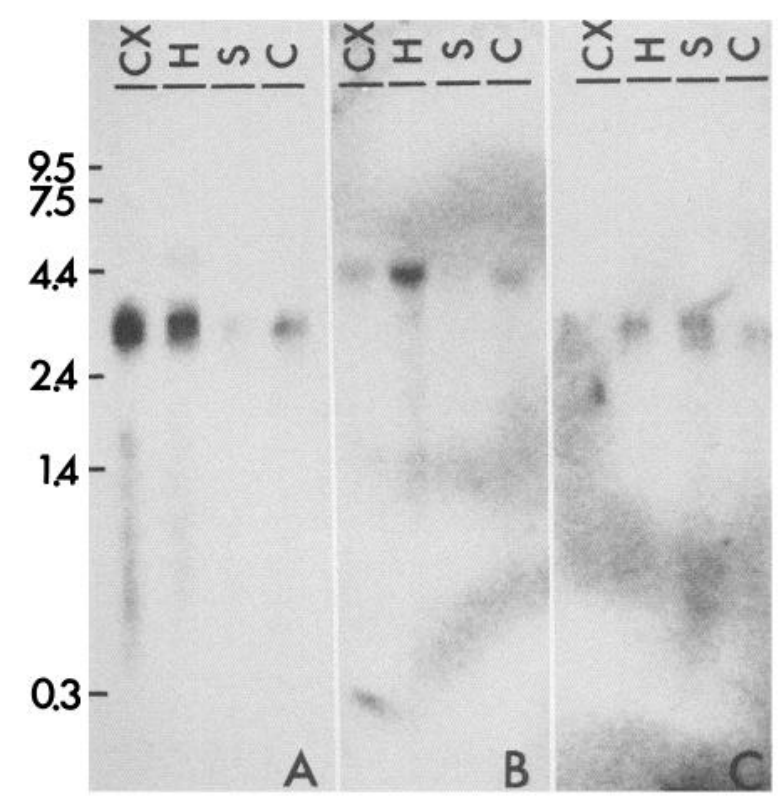

Figure 1. Northern blot analysis of mRNA extracted from rat cerebral cortex $(C X)$, hippocampus $(H)$, striatum $(S)$, and cerebellum $(C)$. RNA, $15 \mu \mathrm{g}$, was applied to each lane and electrophoresed, blotted and hybridized as described in Materials and Methods. Molecular weight standards (BRL RNA ladder) were run in parallel. $A-C$, Blots hybridized to the $\mathrm{m} 1, \mathrm{~m} 3$, and $\mathrm{m} 4$ probes, respectively.

most abundant in cortex and hippocampus, m3 mRNA was relatively abundant in hippocampus, with lesser amounts in cerebral cortex and cerebellum and very little in striatum, while m4 mRNA predominated in striatum and hippocampus with relatively little in cerebral cortex. No hybridization of any probe was observed to mRNA extracted from liver or kidney-tissues that express no muscarinic receptors (data not shown).

In situ hybridization histochemistry revealed each muscarinic receptor mRNA to be uniquely distributed throughout the regions of the CNS examined (Fig. 2).

$m 1 m R N A$ was prevalent in the pyramidal layer of the hippocampus, the granule cell layer of the dentate gyrus, the olfactory nuclei and plexiform layers of the olfactory bulb, the olfactory tubercule, basolateral amygdaloid nuclei, and the piriform cortex. Lesser amounts were also seen in the cerebral cortex and the caudate putamen. A slight laminar distribution was evident in cerebral cortex, where $\mathrm{m} 1 \mathrm{mRNA}$ was predominantly in the more superficial and deeper cortical layers. No hybridization to hindbrain structures was observed.

$m 2 m R N A$ was observed in the pontine nuclei, plexiform layers of the olfactory bulb, medial septal nuclei, and diagonal band. A very low hybridization signal was also seen in thalamic structures, including the habenulae and anteroventral thalamic nuclei upon prolonged exposure of the autoradiograph. No hybridization to cerebral cortex or striatum was evident. This restricted localization may not be a true reflection of $\mathrm{m} 2 \mathrm{mRNA}$ distribution in rat brain since the probe used in this study was based upon the sequence of the human $\mathrm{m} 2$ cDNA reported earlier (Bonner et al., 1987). Since we do not know the degree of sequence similarity between rat and human $\mathrm{m} 2$ receptors, then the relative dearth of $\mathrm{m} 2$ mRNA may be a consequence of a poor match between the human $\mathrm{m} 2$ probe and the rat $\mathrm{m} 2$ mRNA. However, the fact that the $\mathrm{m} 2$ probe used in this study recognizes a $6.2 \mathrm{~kb}$ band in Northern blot analysis of rat atrial 

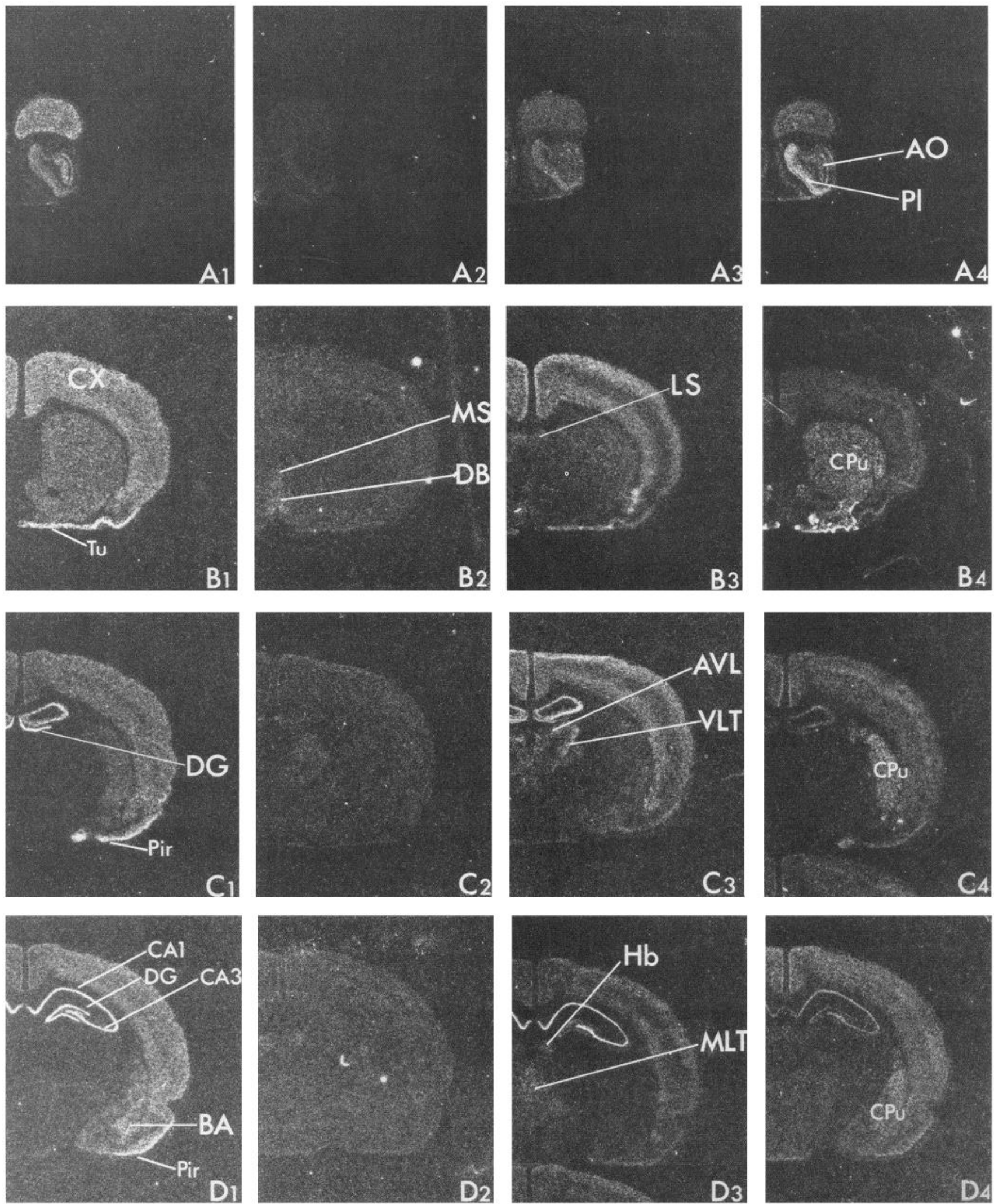

Figure 2. In situ hybridization histochemistry. Coronal sections of rat brain were prepared and hybridized to ${ }^{35}$-tailed probes as described in Materials and Methods. Columns $1-4$ show autoradiographs of $\mathrm{ml}, \mathrm{m} 2, \mathrm{~m} 3$, and $\mathrm{m} 4 \mathrm{mRNA}$ distributions respectively in 7 planes of section $(A-$ $G)$. Abbreviations: $A O$, anterior olfactory nuclei; $A V T$, anteroventral thalamic nuclei; $B A$, basolateral amygdaloid nuclei; $C A 1, C A 2$, and $C A 3$, regions of hippocampus; $C G$, central gray; $C X$, cerebral cortex; $C P u$, caudate putamen; $D B$, diagonal band; $D G$, dentate gyrus; $H b$, habenulae; $L S$, lateral septal nuclei; $M L T$, medial thalamic nuclei; $M S$, medial septal nuclei; Pir, piriform cortex; $P l$, plexiform layers of olfactory bulb; $P n$, pontine nuclei; $S u C$, superior colliculus; $T u$, olfactory tubercle; $V L T$, ventrolateral thalamic nuclei. 

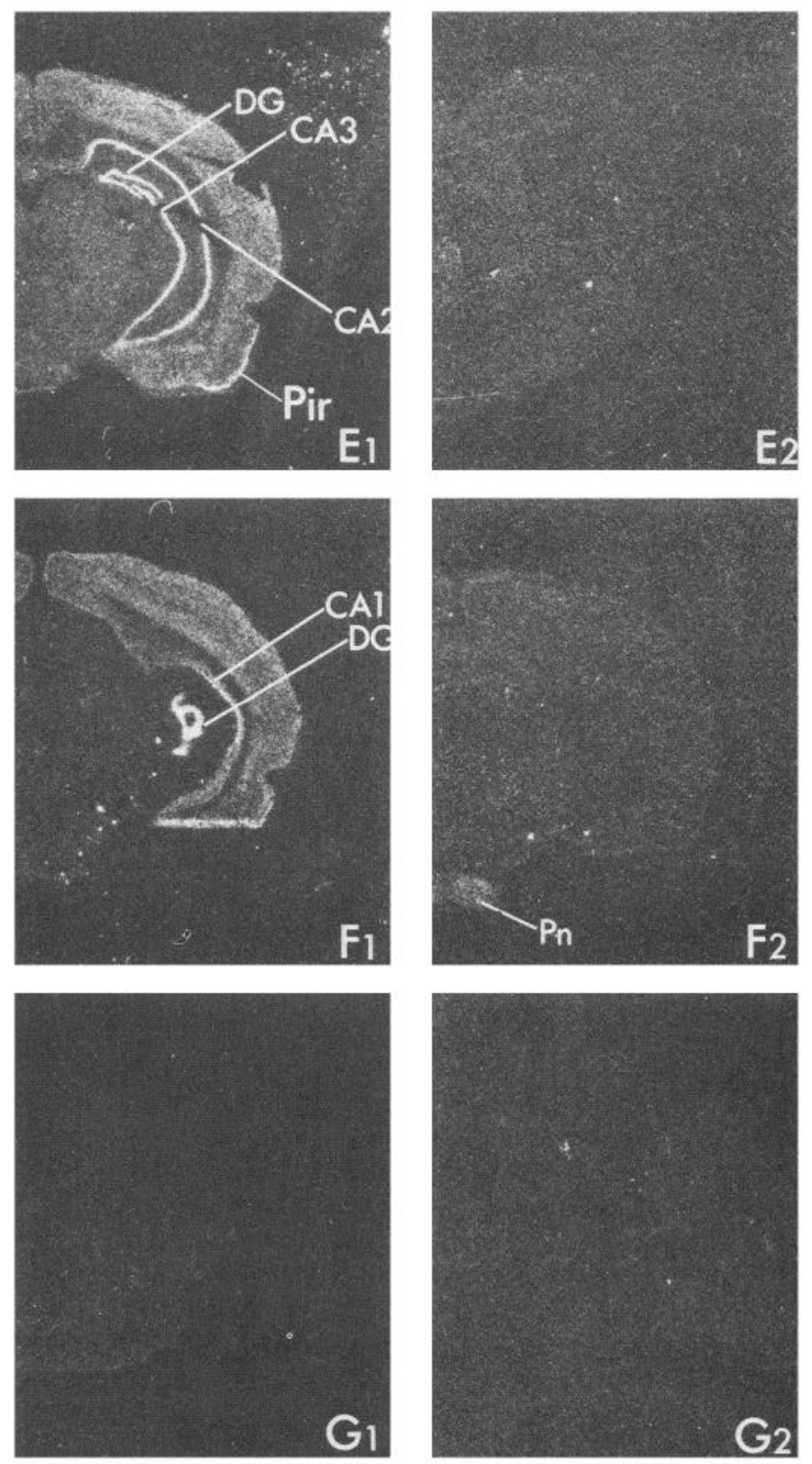
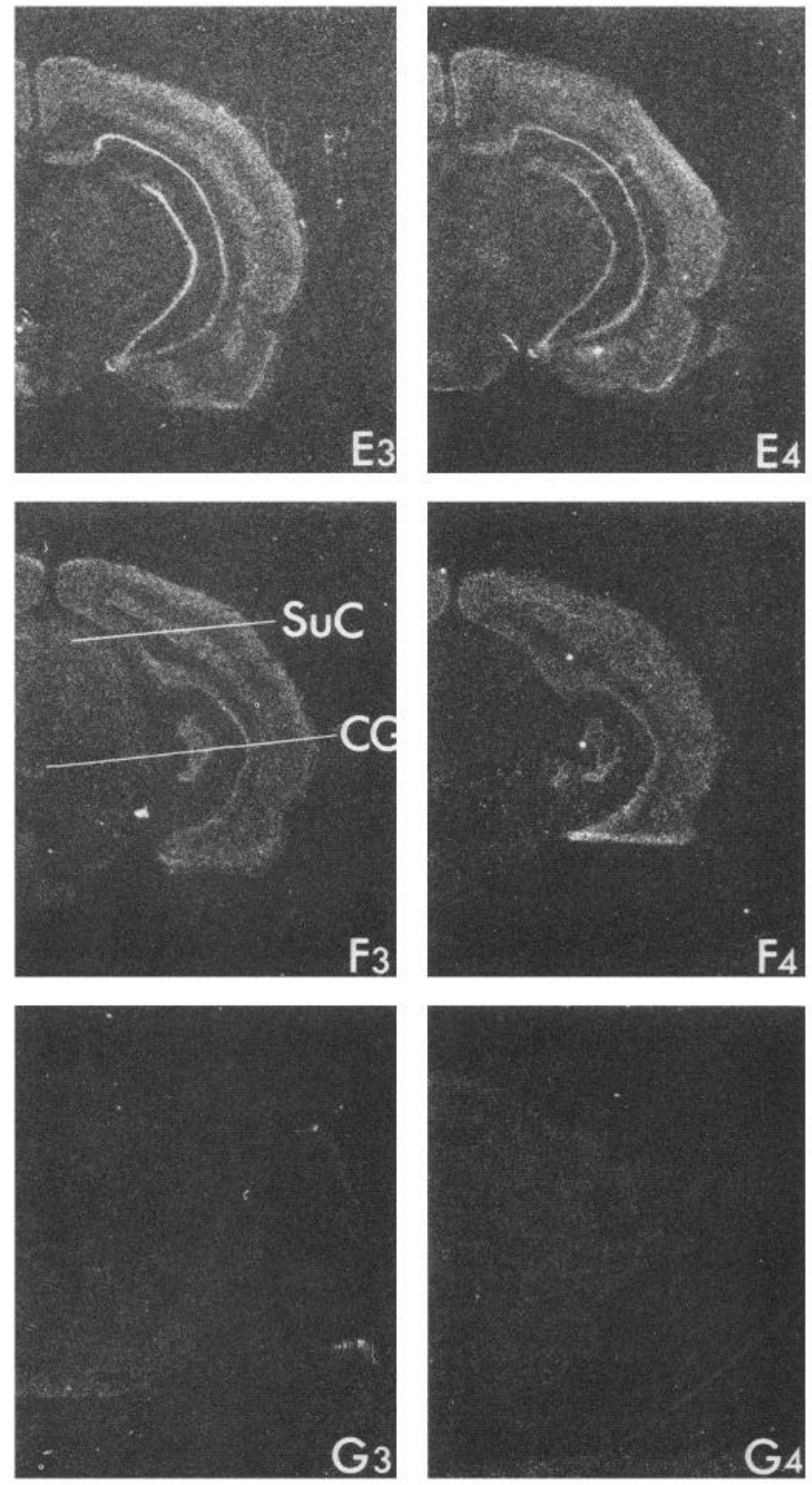

Figure 2. Continued.

mRNA (unpublished observations) suggests that it does recognize rat $\mathrm{m} 2 \mathrm{mRNA}$, although possibly not as efficiently as a probe based on the rat $\mathrm{m} 2$ sequence would.

$m 3 m R N A$ was prominent in the pyramidal cell layer of the hippocampus, but, in contrast to $\mathrm{m} 1 \mathrm{mRNA}$, only low levels were detectable in the dentate gyrus. A similar but more pronounced laminar distribution to that seen with the $\mathrm{ml}$ probe was seen in the cerebral cortex, where m 3 mRNA was predominantly expressed in the superficial and deep layers. Piriform cortex and olfactory tubercule were also heavily labeled. Other labeled areas included the plexiform layers and nuclei of the olfactory bulb and numerous thalamic structures, including the habenulae, the anteroventral, ventrolateral, and midline thalamic nuclei. Low levels of $\mathrm{m} 3$ mRNA were also detected in the lateral septal nuclei and caudate putamen, as well as hindbrain nuclei including the superior colliculus, pontine nuclei, and central gray. $m 4 m R N A$ predominated in the caudate putamen, olfactory bulb, piriform cortex, and pyramidal cell layer of the hippocampus and, as with the $\mathrm{m} 3 \mathrm{mRNA}$, showed relatively little hybridization in the dentate gyrus. Cerebral cortex was relatively evenly labeled, although the midcortical layer appeared more intensely labeled than surrounding cortex. Very low levels of m4 mRNA were detectable in the thalamus and cerebellum.

\section{Discussion}

The results of this study clearly show that at least 4 different muscarinic receptor genes are expressed in rat brain. Furthermore, each muscarinic receptor mRNA has a unique distribution within the CNS.

Numerous workers have mapped muscarinic receptors in the CNS using radioligands to label the receptor. Comparison of the data derived from the use of in vitro autoradiography with in situ hybridization studies is difficult. Since mRNA is present 
only in cell bodies and proximal dendrites, in situ hybridization identifies cell bodies that make the receptor, while in vitro autoradiography localizes the receptor itself. The latter may be on the cell body or on processes distal to the cell body. Comparison is further hindered by the failure of currently available radioligands to specifically label individual muscarinic receptor subtypes. From our pharmacological studies of the $\mathrm{m} 1, \mathrm{~m} 2, \mathrm{~m} 3$, and $\mathrm{m} 4$ receptor cDNAs transfected into COS cells and $L$ cells it is clear that pirenzepine does not distinguish clearly between $\mathrm{m} 1, \mathrm{~m} 3$, and $\mathrm{m} 4$ receptors (Bonner et al., 1987; Brann et al., 1987). Clearly, mapping studies using nonselective ligands such as ${ }^{3} \mathrm{H}-\mathrm{QNB}$ or ${ }^{3} \mathrm{H}-\mathrm{NMS}$ actually localize at least 4 receptors, while ${ }^{3} \mathrm{H}$-pirenzepine labels at least 3 receptors. The overall pattern of receptor distribution as revealed by radioligand binding studies and in vitro receptor autoradiography is that of a predominantly telencephalic location of high-affinity pirenzepine receptors in cerebral cortex, hippocampus, dentate gyrus, and corpus striatum. In contrast, low-affinity pirenzepine receptors are more widespread, being present in a number of hindbrain structures in addition to the forebrain. However, the distribution of muscarinic receptors is in broad agreement with the prevalence of $\mathrm{m} 1, \mathrm{~m} 3$, and $\mathrm{m} 4 \mathrm{mRNA}$ in forebrain and the presence of $\mathrm{m} 2 \mathrm{mRNA}$ in brain-stem structures such as the pontine nuclei.

Autoradiographic localization studies alone cannot directly tell us anything of the functions subserved by each receptor subtype. However, the fact that such a multiplicity of responses to muscarinic receptor activation is known to occur in the CNS (North, 1986; Nathanson, 1987) and the current demonstration of a heterogeneous expression of 4 different muscarinic receptor genes warrants of comparison of the known responses with the receptor mRNA distributions described in this study. However, it is worth pointing out that there is no evidence that the relative abundances of receptor proteins are reflected in the relative abundances of their mRNAs since individual mRNAs could differ in their translation efficiencies. Furthermore, the data presented here may be incomplete since other muscarinic receptor subtypes may exist that have not yet been identified. Nevertheless, such comparisons may provoke novel insights into the responses that may be transduced by each muscarinic receptor.

\section{Cerebral cortex}

Activation of muscarinic receptors in rat cortex stimulates phosphoinositide hydrolysis (Downes, 1982) and give rise to both a synaptic inhibition and a slow excitation (Krnjevic et al., 1971; Krnjevic, 1974). In guinea pig cortex pyramidal neurones, slow excitation occurs by inhibition of a voltage-dependent $\mathrm{K}^{+}$current ( $\mathrm{M}$ current; Brown and Adams, 1980) and is mediated by a high affinity pirenzepine receptor (McCormick and Prince, 1985). In contrast, inhibition is believed to occur by excitation of muscarinic receptors on inhibitory interneurons that have a low affinity for pirenzepine (McCormick and Prince, 1985). Stimulation of phosphoinositide hyrolysis in cerebral cortex is also mediated by a high-affinity pirenzepine receptor (Brown et al., 1984; Lazareno et al., 1985). Inhibition of the M-current by muscarinic agonists has also been described in the piriform cortex (ffrench-Mullen et al., 1983) and olfactory bulb (Constanti and Galvan, 1983), both regions that express $\mathrm{m} 1, \mathrm{~m} 3$, and $\mathrm{m} 4$ mRNAs. The coexpression of $\mathrm{m} 1, \mathrm{~m} 3$, and $\mathrm{m} 4$ muscarinic receptor genes in cerebral cortex indicates that stimulation of phosphoinositide hydrolysis and inhibition of M-current could be mediated by up to 3 muscarinic receptors. Numerous localization studies have demonstrated a prevalence of high-affinity pirenzepine sites in cortical layers II, III, and VI. From the distribution of the $\mathrm{m} 3 \mathrm{mRNA}$ across the cortex it would appcar that this laminar distribution may be largely due to a heterogeneous distribution of $\mathrm{m} 3$ receptors. An exception to the coexpression of $\mathrm{m} 1, \mathrm{~m} 3$, and $\mathrm{m} 4$ receptor mRNA in cortex is provided by the exclusive presence of $\mathrm{ml}$ mRNA in the basolateral amygdaloid nuclei. Interestingly, chemical kindling of this locus by muscarinic agonists is used as an animal model of epilepsy (McNamara, 1978; Wasterlain and Jones, 1981).

\section{Hippocampus}

Numerous responses are elicited in hippocampus by activation of muscarinic receptors. These include: inhibition of the M-current (Halliwell and Adams, 1982); inhibition of a slow after hyperpolarization caused by activation of a $\mathrm{Ca}^{2+}$-activated $\mathrm{K}^{+}$ conductance (Cole and Nicoll, 1984); a membrane depolarization (Bernardo and Prince, 1982; Cole and Nicoll, 1984); an inhibition of a fast, transient $\mathrm{K}^{+}$current (Nakajima ct al., 1986); reduction of a $\mathrm{Ca}^{2+}$ current (Gahwiler and Brown, 1987) and stimulation of phosphoinositide hydrolysis (Downes, 1982; Gil and Wolfe, 1985). Clearly the expression of at least 3 different muscarinic receptor genes in hippocampus offers the potential for specific identification of these responses with individual receptor types. At present, characterization of these responses with respect to inhibition by pirenzepine has been carried out only for stimulation of phosphoinositide hydrolysis, which has been shown to be coupled to a receptor expressing a high affinity towards pirenzepine (Gil and Wolfe, 1985; Fisher, 1986). The observation that $m 1$ receptors are the dominant subtype found in the dentate gyrus is interesting since muscarinic receptors in the dentate gyrus are specifically down-regulated in kindled animals (Dasheiff et al., 1982; Savage and McNamara, 1982; Savage et al., 1983), thus lending further support to the idea that $\mathrm{m} 1$ reccptors play a role in seizure formation.

\section{Striatum}

Two major responses to muscarinic receptor activation have been characterized in striatum. First, a presynaptic augmentation of dopamine release from striatal nerve terminals has been demonstrated. Unlike most other presynaptic actions of $\mathrm{ACh}$, this response appears to be mediated by a high-affinity pirenzepine receptor (Raiteri et al., 1984; James and Cubeddu, 1987). However, no muscarinic receptor mRNA was detected in the substantia nigra, the area that projects dopaminergic neurons to the striatum. Stimulation of muscarinic receptors also causes an inhibition of adenylate cyclase, a response mediated by a low-affinity pirenzepine receptor (Gil and Wolfe, 1985). The functions subserved by striatal $\mathrm{m} 1, \mathrm{~m} 3$, and $\mathrm{m} 4$ receptors remain to be elucidated.

\section{Thalamus}

Much less is known about muscarinic receptors in thalamus, although autoradiographic and radioligand binding studies have shown most receptors to be of the low-affinity pirenzepine type (Cortes and Palacios, 1986; Cortes et al., 1986; Mash and Potter, 1986). Muscarinic stimulation of reticular thalamic neurons leads to a hyperpolarization due to an increase in $\mathrm{K}^{+}$conductance that is mediated by a low-affinity pirenzepine type of receptor (McCormick and Prince, 1986). Accordingly the low levels of $\mathrm{m} 2$ mRNA found in the thalamic nuclei may encode the receptor responsible for this hyperpolarization. We are unaware of any thalamic response that has been linked to a high-affinity pirenzepine type receptor that may be encoded by the $\mathrm{m} 3 \mathrm{mRNA}$ 
detected in the thalamus; however, it would appear that $\mathrm{m} 3$ receptors may constitute the low amounts of high-affinity pirenzepine receptors that have been described in thalamus.

\section{Pons}

As in the thalamus, activation of muscarinic receptors in the pontine reticular nucleus has been demonstrated to cause a hyperpolarization due to a rise in $\mathrm{K}^{+}$conductance mediated by a low-affinity pirenzepine receptor (Egan and North, 1986). A low-to intermediate-affinity pirenzepine receptor is also coupled to phosphoinositide hydrolysis in the pons (Lazareno et al., 1985). As suggested in the case of the thalamus, the $m 2$ receptor could be responsible for this action.

\section{Septum}

Cells of the medial septum, diagonal band of Broca and Meynerts nucleus give rise to the chief cholinergic projection to the cerebral cortex and hippocampus (Lewis et al., 1967; Shute and Lewis, 1967). Inhibition of $\mathrm{ACh}$ release by muscarinic autoreceptors on cholinergic nerve terminals occurs in both cerebral cortex and hippocampus (Marchi et al., 1981; Marchi and Raiteri, 1984; Raiteri et al., 1984; Meyer and Otero, 1985). The receptor mediating this action has been characterized as a lowaffinity pirenzepine type. $m$ RNA encoding presynaptic receptors would be anticipated to be found in cholinergic nerve cell bodies that project to the target areas. Hence, $\mathrm{m} 2 \mathrm{mRNA}$ detected in the medial scptum and diagonal band may thus cncode the receptors that are subsequently transported to nerve terminals in the cortex and hippocampus, where they act as inhibitory presynaptic autoreceptors. This is of potential clinical importance since Alzheimer's disease is accompanied by a degeneration of septal nuclei (Coyle et al., 1983) and a decline of lowaffinity pirenzepine receptors in cerebral cortex (Mash et al., 1985).

\section{Cerebellum}

The results obtained with the cerebellum remain enigmatic in that Northern analysis shows the presence of $\mathrm{m} 1, \mathrm{~m} 3$, and $\mathrm{m} 4$ mRNAs, yet in situ hybridization reveals little labeling in the sections examined. A likely possibility is that muscarinic receptor mRNA is present in discrete nuclei that contributed to the total RNA extracted from the cerebellum but were not present in the sections examined in this study. Further experiments are underway to examine the possibility.

Our data illustrate the differential expression of 4 muscarinic receptor genes in the CNS. It should be noted, however, that these data may not provide a complete description of muscarinic receptor expression in the CNS since there is evidence for the existence of additional muscarinic receptors. First, hybridization of rat and human genomic DNA with $\mathrm{m} 1$ receptor cDNA indicates the presence of at least one more closely related gene in the rat and human genomes (Bonner et al., 1987) and potentially several others. Second, pharmacological studies using a novel antagonist, AF-DX 116 (Hammer et al., 1986) have indicated the presence of 2 low-affinity pirenzepine receptors subtypes; a low- to intermediate-affinity pirenzepine/high-affinity AF-DX 116 type (cardiac type) and a low-affinity pirenzepine/ low-affinity AF-DX 116 type (glandular type). The $\mathrm{m} 3$ receptor has the pharmacological properties of glandular receptors (unpublished observations). Also, it is clear that each muscarinic receptor is linked to a specific subset of effector mechanisms and this may underlie the heterogeneous distribution of receptor mRNA observed here (Jones et al., 1988). Answers to these questions must await derivation of pharmacological probes capable of specifically interacting with only one receptor subtype.

Note added in proof. Subsequent to the submission of this manuscript, Peralta et al. (1987) reported the cloning of human genes for the same 4 muscarinic receptors but used a different nomenclature. Their M1, M2, M4 and M3 correspond to our $\mathrm{m} 1, \mathrm{~m} 2, \mathrm{~m} 3$, and $\mathrm{m} 4$, respectively, i.e., $\mathrm{M} 4=\mathrm{m} 3$ and $\mathrm{M} 3=$ m4 (Bonner et al., 1987).

The recent cloning of a rat $\mathrm{m} 2 \mathrm{cDNA}$ (Gocayne et al., 1987) has allowed us to compare the human $\mathrm{m} 2$ and the rat $\mathrm{m} 2$ sequences corresponding to the oligonucleotide probe used in this study. Out of 48 nucleotides there are only 5 mismatches (i.e., $90 \%$ homology) that are distributed fairly evenly throughout the length of the probe. These mismatches will clearly destabilize the hybrid between the human probe and the rat mRNA, but the extent to which this occurs may only be determined empirically. The fact that this probe hybridizes to a $6.2 \mathrm{~kb} \mathrm{~m} 2$ RNA in rat atria is the most direct evidence of its fidelity.

\section{References}

Benardo, L. S., and D. A. Prince (1982) Ionic mechanisms of cholinergic excitation in mammalian hippocampal pyramidal cells. Brain Res. 249: 333-344

Birdsall, N. J. M., A. S. V. Burgen, and E. C. Hulme (1978) The binding of agonists to brain muscarinic receptors. Mol. Pharmacol. 14: 723-736.

Bonner, T. I., N. J. Buckley, A. Young, and M. R. Brann (1987) Identification of a family of muscarinic receptor genes. Science 237:527532.

Brann, M. R., N. J. Buckley, S. V. P. Jones, and T. Bonner (1987) Expression of a cloned muscarinic receptor in A9 L cells. Mol. Pharmacol. 32: 450-455.

Brown, D. A., and P. R. Adams (1980) Muscarinic suppression of a novel voltage-sensitive $\mathrm{K}^{+}$current in a vertebrate neurone. Nature 283: 673-676.

Brown, E., D. A. Kendall, and S. R. Nahorski (1984) Inositol phospholipid hydrolysis in rat cerebral cortical slices: 1 . Receptor characterisation. J. Neurochem. 42: 1379-1387.

Chirgwin, J. M., R. J. Przybyla, R. J. Macdonald, and W. J. Rutter (1979) Isolation of biologically active ribonucleic acid from sources enriched in ribonuclease. Biochemistry 18: 5294-5299.

Cole, A. E., and R. A. Nicoll (1984) Characterisation of a slow cholinergic postsynaptic potential recorded in vitro from rat hippocampal pyramidal cells. J. Physiol. (Lond.) 352: 173-188.

Constanti, A., and M. Galvan (1983) M-current in voltage clamped olfactory cortex neuron. Neurosci. Lett. 39: 65-70.

Cortes, R., and J. M. Palacios (1986) Muscarinic cholinergic receptor subtypes in the rat brain. 1. Quantitative autoradiographic studies. Brain Res. 362: 227-238.

Cortes, R., A. Probst, and J. M. Palacios (1984) Quantitative light microscopic autoradiographic localisation of cholinergic muscarinic receptors in the hurian brainstem. Neuroscience 12: 1003-1026.

Cortes, R., A. Probst, H.-J. Tobler, and J. M. Palacios (1986) Muscarinic cholinergic receptor subtypes in the human brain. 2. Quantitative autoradiographic studies. Brain Res. 362: 239-253.

Coyle, J. T., D. L. Price, and M. R. Delong (1983) Alzheimer's disease: A disorder of cortical cholinergic innervation. Science 219: 11841190.

Dasheiff, R. M., D. D. Savage, and J. O. McNamara (1982) Seizures down-regulate muscarinic cholinergic receptors in hippocampal formation. Brain Res. 235: 327-334.

Downes, C. P. (1982) Receptor-stimulated inositol phospholipid metabolism in the central nervous system. Cell Calcium 3: 413-428.

Egan, T. M., and R. A. North (1986) Acetylcholine hyperpolarises central neurones by acting on an $\mathbf{M}_{2}$ muscarinic receptor. Nature 319: 405-407.

ffrench-Mullen, J. M. H., N. Hori, H. Nakanishi, N. T. Slater, and D. O. Carpenter (1983) Asymmetric distribution of acetylcholine receptors and $\mathrm{M}$ channels on prepyriform neurons. Cell. Mol. Neurobiol. 3: 163-181. 
Fisher, S. K. (1986) Inositol lipids and signal transduction at CNS muscarinic receptors. Trends Pharmacol. Sci. Suppl. 61-65.

Gahwiler, B. H., and D. A. Brown (1987) Muscarine affects calciumcurrents in rat hippocampal pyramidal cells in vitro. Neurosci. Lett. 76: 301-306.

Gil, D. W., and B. B. Wolfe (1985) Pirenzepine distinguishes between muscarinic receptor-mediated phosphoinositide breakdown and inhibition of adenylate cyclase. J. Pharmacol. Exp. Ther. 232: 608-616.

Gocayne, J., D. A. Robinson, M. G. FitzGerald, F.-Z. Chung, A. R. Kerlavage, K.-U. Lentes, J. Lai, C.-D). Wang, C. M. Fraser, and J. C. Venter (1987) Primary structure of rat cardiac $\beta$-adrenergic and muscarinic cholinergic receptors obtained by automated DNA sequence analysis: Further evidence for a multigene family. Proc. Natl. Acad. Sci. USA 84: 8296-8300.

Goyal, R. K., and S. Rattan (1978) Neurohumoral, hormonal, and drug receptors for the lower esophageal sphincter. Gastroenterology 74: 598-619.

Halliwell, J. V., and P. R. Adams (1982) Voltage-clamp analysis of muscarinic excitation in hippocampal neurons. Brain Res. 250:7192.

Hammer, R., C. P. Berrie, N. J. M. Birdsall, A. S. V. Burgen, and E. C. Hulme (1980) Pirenzepine distinguishes between different subclasses of muscarinic receptor. Nature 283: 90-92.

Hammer, R., E. Giraldo, G. B. Schiavi, E. Montefereni, and H. Ladinsky (1986) Binding profile of a novel cardioselective muscarine receptor antagonist, AF-DX 116, to membranes of peripheral tissues and brain in the rat. Life Sci. 38: 1653-1662.

James, M. K., and L. X. Cubeddu (1987) Pharmacologic characterisation and functional role of muscarinic autoreceptors in the rabbit striatum. J. Pharmacol. Exp. Ther. 240: 203-215.

Jones, S. V. P., J. L. Barker, N. J. Buckley, T. I. Bonner, R. M. Collins, and M. R. Brann (1988) Cloned muscarinic receptor subtypes expressed in $A 9 \mathbf{L}$ cells differ in their coupling to electrical responses. Mol. Pharm. (in press).

Kmjevic, K. (1974) Chemical nature of synaptic transmission in vertebrates. Physiol. Rev. 54: 418-540.

Krnjevic, K., R. Pumain, and L. Renaud (1971) The mechanism of excitation by acetylcholine in the cerebral cortex. J. Physiol. (Lond.) 215: 247-268.

Kubo, T., K. Fukuda, A. Mikami, A. Maeda, H. Takahashi, M. Mishina, K. Haga, A. Ichiyama, K. Kangawa, M. Kojima, H. Matsuo, T. Hirose, and S. Numa (1986a) Cloning, sequencing and expression of complementary DNA encoding the muscarinic acetylcholine receptor. Nature 323: 411-416.

Kubo, T., A. Maeda, K. Sugimoto, I. Akiba, A. Mikami, H. Takahashi, T. Haga, K. Haga, A. Ichiyama, K. Kangawa, H. Matsuo, M. Mishina, T. Hirose, and S. Numa (1986b) Primary structure of porcine cardiac muscarinic acetylcholine receptor deduced from the cDNA sequence. FEBS Lett. 209: 367-372.

Lazareno, S., D. A. Kendall, and S. R. Nahorski (1985) Pirenzepine indicates heterogeneity of muscarinic receptors linked to cerebral inositol phospholipid metabolism. Neuropharmacology 24: 593-595.

Lewis, P. R., C. C. D. Shute, and A. Silver (1967) Confirmation from choline acetylase of a massive cholinergic innervation to the rat hippocampus. J. Physiol. (Lond.) 191: 215-224.

Marchi, M., and M. Raiteri (1984) On the presence in the cerebral cortex of muscarinic receptor subtypes which differ in neuronal localisation, function and pharmacological properties. J. Pharmacol. Exp. Ther. 235: 230-233.

Marchi, M., P. Paudice, and M. Raiteri (1981) Autoregulation of acetylcholine release in isolated hippocampal nerve endings. Eur. J. Pharmacol. 73: 75-79.

Mash, D. C., and L. T. Potter (1986) Autoradiographic localisation of M1 and M2 muscarine receptors in the rat brain. Neuroscience 19: $551-564$.
Mash, D. C., D. D. Flynn, and L. T. Potter (1985) Loss of M2 muscarine receptors in the cerebral cortex in Alzheimer's disease and experimental cholinergic denervation. Science 228: 1115-1117.

McCormick, D. A., and D. A. Prince (1985) Two types of muscarinic response to acetylcholine in mammalian cortical neurons. Proc. Natl. Acad. Sci. USA 82: 6344-6348.

McCormick, D. A., and D. A. Prince (1986) Acetylcholine induces burst firing in thalamic reticular neurones by activating a potassium conductance. Nature 319: 402-405.

McNamara, J. O. (1978) Muscarinic cholinergic receptors participate in the kindling model of epilepsy. Brain Res. 154: 415-420.

Meyer, E. M., and D. H. Otero (1985) Pharmacological and ionic characterisations of the muscarinic receptors modulating ${ }^{3} \mathrm{H}$-acetylcholine release from rat cortical synaptosomes. J. Neurosci. 5: 12021207

Nakajina, Y., S. Nakajima, R. J. Leonard, and K. Yamaguchi (1986) Acetylcholine raises excitability by inhibiting the fast transient potassium current in cultured hippocampal neurons. Proc. Natl. Acad. Sci. USA 83: 3022-3026.

Nathanson, N. M. (1987) Molecular properties of the muscarinic acetylcholine receptor. Annu. Rev. Neurosci. 10: 195-236.

Nonaka, R., and T. Moroji (1984) Quantitative autoradiography of muscarinic cholinergic receptors in the rat brain. Brain Res. 296: 295303.

North, R. A. (1986) Muscarinic receptors and membrane ion conductances. Trends Pharmacol. Sci. Suppl. 19-22.

Peralta, E. G., J. W. Winslow, G. L. Peterson, D. H. Smith, A. Ashkenazi, J. Ramachandran, M. I. Schimerlick, and D. J. Capon (1987) Primary structure and biochemical properties of an $\mathrm{M}_{2}$ muscarinic receptor. Science 236: 600-605.

Raiteri, M., R. Leardi, and M. Marchi (1984) Heterogeneity of presynaptic muscarinic receptors regulating neurotransmitter release in the rat brain. J. Pharmacol. Exp. Ther. 228: 209-214.

Rotter, A., N. J. M. Birdsall, A. S. V. Burgen, P. M. Field, E. C. Hulme, and $G$. Raisman (1979) Muscarinic receptors in the central nervous system of the rat.1. Technique for autoradiographic localisation of the binding of ${ }^{3} \mathrm{H}$-propylbenzilylcholine mustard and its distribution in the forebrain. Brain Res. Rev. 1: 141-165.

Savage, D. D., and J. O. McNamara (1982) Kindled seizures selectively reduce a subpopulation of ${ }^{3} \mathrm{H}$-quinuclidinyl benzilate binding sites in rat dentate gyrus. J. Pharmacol. Exp. Ther. 222: 670-673.

Savage, D. D., R. M. Dasheiff, and J. O. McNamara (1983) Kindled seizure-induced reduction of muscarinic receptors in rat hippocampal formation: Evidence for localisation to dentate granule cells. J. Comp. Neurol. 221: 106-112.

Shute, C. C. D., and P. R. Lewis (1967) The ascending cholinergic reticular system; neocortical, olfactory and subcortical projections. Brain 90: 497-520.

Spencer, D. G., E. Horvath, and J. Traber (1986) Direct autoradiographic determination of M1 and M2 muscarinic acetylcholine receptor distribution in the rat brain: Relation to cholinergic nuclei and projections. Brain Res. 380: 59-68.

Wamsley, J. K., M. S. Lewis, W. S. Young III, and M. J. Kuhar (1981) Autoradiographic localisation of muscarinic receptors in rat brainstem. J. Neurosci. 1 : 176-191.

Wamsley, J. K., D. R. Gehlert, W. R. Roeske, and H. I. Yamamura (1984) Muscarinic antagonist binding site heterogeneity as evidenced by autoradiography after direct labeling with ${ }^{3} \mathrm{H}-\mathrm{QNB}$ and ${ }^{3} \mathrm{H}$-pirenzepine. Life Sci. 34: 1395-1402.

Wasterlain, C. G., and V. Jones (1981) Cholinergic kindling of the amygdala requires the activation of muscarinic receptors. Exp. Neurol. 73: 595-599.

Young III, W. S., T. I. Bonner, and M. R. Brann (1986) Mesencephalic dopamine neurons regulate the expression of neuropeptide mRNAs in the rat forebrain. Proc. Natl. Acad. Sci. USA 83: 9827-9831. 